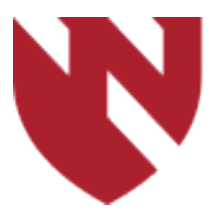

December 2019

\title{
When it's not Just Hypothyroidism
}

Preethi Polavarapu

University of Nebraska Medical Center

Whitney S. Goldner

University of Nebraska Medical Center

Tell us how you used this information in this short survey.

Follow this and additional works at: https://digitalcommons.unmc.edu/gmerj

Part of the Higher Education Commons, and the Medicine and Health Sciences Commons

\section{Recommended Citation}

Polavarapu, P., , Goldner, W. S. When it's not Just Hypothyroidism. Graduate Medical Education Research Journal. 2019 Dec 13; 1(1).

https://digitalcommons.unmc.edu/gmerj/vol1/iss1/31

This Conference Proceeding is brought to you for free and open access by DigitalCommons@UNMC. It has been accepted for inclusion in Graduate Medical Education Research Journal by an authorized editor of DigitalCommons@UNMC. For more information, please contact digitalcommons@unmc.edu. 


\section{When it's not Just Hypothyroidism}

\section{Creative Commons License}

(c) $($ ) (2)

This work is licensed under a Creative Commons Attribution-Noncommercial-No Derivative Works 4.0 License. 
correctly identified relative afferent pupillary defect (RAPD) while 88\% (111) students and $95 \%$ (18) residents correctly identified Horner's syndrome. 97\% (123) students and $95 \%$ (18) residents correctly used appropriate pharmacological drops to confirm Horner's pupil. Post training, students reported improved confidence in identification of all

5 pupillary abnormalities $(\mathrm{p}=0.00)$, while residents reported most improvement in the confidence in diagnosing Adie pupil $(\mathrm{p}=0.00)$

\section{When It's Not Just Hypothyroidism Preethi Polavarapu, Whitney S Goldner}

Mentor: Whitney S Goldner

Program: Diabetes, Endocrinology, and Metabolism

Background: Autoimmune Polyglandular Type II Syndrome is characterized by Autoimmune Thyroid disease, Type1 Diabetes, and Primary Adrenal Insufficiency. Twenty percent of the persons with APS II

can simultaneously present with symptoms of adrenal insufficiency and thyroid disease. In these patients, replacement of thyroid hormone before cortisol can precipitate adrenal crisis.

Methods: A middle-aged patient presented to the endocrine clinic with fatigue, unintentional weight loss, nausea, abdominal pain and syncope. Initial labs with the PCP showed elevated TSH at $6.6 \mathrm{mcIU} / \mathrm{ml}$, normal T4 $0.8 \mathrm{ng} / \mathrm{dl}$ consistent with subclinical hypothyroidism. The patient was started on levothyroxine but symptoms worsened despite and using pharmacologic agent to confirm anisocoria $(\mathrm{p}=0.00)$.

Conclusion: All trainees showed significant improvement in confidence and competence in pupillary examination after using the APS. Virtual-reality based practical training can shorten time to competency for critical medical examination techniques.

https://doi.org/10.32873/unmc.dc.gmerj.1.1.030 normalization of thyroid function tests. The patient presented to us for further evaluation. On examination the patient was tan, blood pressure was 100/56mmHg. Labs showed Sodium $133 \mathrm{mmol} / 1$, Potassium $4.5 \mathrm{mmol} / 1$, TSH $2.5 \mathrm{mcIU} / \mathrm{ml}$, T4 $1 \mathrm{ng} / \mathrm{dl}$, Bicarbonate $24 \mathrm{mmol} / \mathrm{l}$. Given the patient's worsening symptoms despite normalization of thyroid function tests and electrolyte abnormalities she was evaluated for adrenal insufficiency.

Results: Labs showed random cortisol level $0.4 \mathrm{mcg} / \mathrm{dl}$, ACTH stimulation showed cortisol level at 0.30, 60 minutes was $<0.4$ $\mathrm{mcg} / \mathrm{dl}$, ACTH level $951 \mathrm{pg} / \mathrm{ml}$, aldosterone $<3 \mathrm{ng} / \mathrm{dl}$, renin $0.5 \mathrm{ng} / \mathrm{ml} / \mathrm{hr}$ consistent with adrenal insufficiency. Levothyroxine was held for 1 week, hydrocortisone and fludrocortisone was initiated and symptoms improved dramatically.

Conclusion: Multiple endocrinopathies can present in persons with APS II. This

\section{Papillary Thyroid Cancer in the Ovaries? A Case of Struma Ovarii Sapna Raghunathan, Anery Patel}

Mentor: Anery Patel

Program: Diabetes, Endocrinology, and Metabolism

Background: Struma ovarii is a specialized teratoma predominantly composed of mature thyroid tissue. Accounts for 5\% of all teratomas. They could be benign or malignant, compose $>50 \%$ of overall tissue, to be categorized as struma ovarii. Clinical and biochemical findings of hyperthyroidism are uncommon. Here, we present a case of struma ovarii with co-existing thyroid nodules.

Methods: This is a middle-aged patient with no past medical history, who presented to the PCP with dysmenorrhea and menorrhagia. The patient was found to have a complex 8 $\mathrm{cm}$ ovarian cyst with normal CA-125. The patient underwent a right oophorectomy and bilateral salpingectomy for removal of the mass. Pathology showed the ovarian cyst wall containing thyroid tissue, mostly benign, but with two small foci of follicular variant of papillary carcinoma in the background of struma ovarii.

Initial thyroid function tests showed a TSH of 4.44 and thyroglobulin levels within normal range. Ultrasound of the thyroid gland, showed a $1 \mathrm{~cm}$ nodule with a 5-20\% risk of malignancy, but too small to biopsy. Considering the need to monitor disease recurrence with tumor markers, the patient underwent a total thyroidectomy.

Results: Pathology of the thyroid gland showed lymphocytic thyroiditis with no evidence of malignancy.

Conclusions: Thyroid cancer metastatic to the ovary can be confused with true struma ovarii. Primary thyroid cancer rarely metastasizes to the ovary, and in these cases, the ovary does not have teratomatous features. patient presented with both Primary Adrenal Insufficiency and Primary Hypothyroidism. Symptoms of hypothyroidism and adrenal insufficiency can be nonspecific, so a high index of suspicion is needed to evaluate for other causes if symptoms worsen after initiating levothyroxine.

https://doi.org/10.32873/unmc.dc.gmerj.1.1.031

Thyroidectomy helps to monitor recurrence, as thyroglobulin can then be produced only by the tumor.

https://doi.org/10.32873/unmc.dc.gmerj.1.1.032 